\author{
Sirje Helme
}

\title{
JAAK KANGILASKI - SCHOLAR AND TEACHER
}

Among Estonian art historians we have our own goal setters and perhaps even schools of thought. Jaak Kangilaski, the professor emeritus of two academic institutions - both the University of Tartu and the Estonian Academy of Arts - is definitely one of those we can consider to be a goal setter. It is impossible to imagine the study of post-war art history, and some of the significant conclusions drawn thereupon, without his writings. Jaak Kangilaski combines the best traits of a scholar - a thorough knowledge of the material, a clear theoretical point of departure, personal relationship with the material and outstanding teaching and lecturing abilities.

Although Jaak Kangilaski's thesis, which he wrote in 1969 and defended at the University of Tartu, was about the Les Nabis ${ }^{1}$, a somewhat symbolist and esoteric pre-World War I group of artists, and later he has also readily come back to the revolutionary time at the end of the $19^{\text {th }}$ century in his articles, his life's work has become researching post-war Estonian art with the focus on the years from 1940 to 1960. His being the compiler and editor, as well as primary author of part 1 of volume 6 of the History of Estonian Art, has made the chapters about the three waves of Stalinism, the period of the German occupation and the forced

DOI: http://dx.doi.org/10.12697/BJAH.2014.8.07

Translation by Juta Ristsoo

1 Jaak Kangilaski, Kunstnikerühmitus “Les Nabis” ja nende osa prantsuse 19. Sajandi lõpu ja 20. Sajandi alguse maalikunstis, juhendaja Vladimir Levinson-Lessing (Tartu: Tartu Riiklik Üikool, 1969). 
Fig. 1. Jaak Kangilaski, at the anniversary celebration of the Art Museum of Estonia, 17 November 2012. Photo: EKM Archives.

exile of many artists into the best and most thorough survey of the most grievous period in Estonian art - the years from 1941 to $1953 .^{2}$

As an art historian, Jaak Kangilaski's methodical approach has always been based on historical and social research. That which is self-evident today was not necessary so in the early years of his academic career. Or more precisely, the requirement at that time to link art and society in the context of the Marxist superstructure was certainly different from how Kangilaski elucidated that relationship. His interest in how society functions in the broadest sense, which dated back to his youth,

2 Eesti Kunsti Ajalugu/ History of Estonian Art 1940-1991, I. Koostaja ja toimetaja Jaak Kangilaski (Tallinn: Eesti Kunstiakadeemia, 2013). 
was behind this. This interest was so strong that art history was not his priority when making his choices upon entering university. And yet, he defended his thesis in the subject of art history. Jaak Kangilaski has written, "My focus on art history was not based on an interest in art as a value in and of itself, and definitely not, on a desire for aesthetic enjoyment, but primarily on the realisation that art history would allow me to deal with the problems of the recent past and the present day more honestly." ${ }^{3}$

During his long and successful career, ${ }^{4}$ Jaak Kangilaski, as an art historian, has dedicated himself to two subjects $-20^{\text {th }}$-century art and art theory and the problems of post-war Estonian art, and he has been the main author of the methodology in this area.

After graduating from university, Jaak Kangilaski quickly became one of the esteemed proponents of $20^{\text {th }}$-century Western art. He has said that an important reason for this that the nature of Western modernism and avant-garde counterbalanced Soviet culture. Many of his presentations and lectures from that period have also appeared as articles; some have been published in his collection of articles titled About Art, Estonia and Estonian Art ${ }^{5}$. Despite the fact that, at that time, getting the relevant information, developing a totally adequate picture based on the fragments of information that were obtained, and writing about it objectively in the Soviet press was fraught with difficulties, these articles ${ }^{6}$ were the only information available to most artists and ordinary people about the art processes underway in the West. During the 1970s the field of information slowly widened and miraculously a few trips to the West became possible. The radical changes in Western art life during the 1960s were very difficult to interpret based only on texts, and the direct observation of the events enabled a more critical approach. Jaak Kangilaski's articles changed from being introductory surveys to providing increasingly critical insights into the problems of post-war

3 Jaak Kangilaski, “Autor iseendast - Jaak Kangilaski”, Kunstist, Eestist ja eesti kunstist (Tartu: Ilmamaa, 2000), 9.

4 Between 1989 and 1995, Professor Jaak Kangilaski was the rector of the State Art Institute of the Estonian S.S.R. (currently the Estonian Academy of Arts); from 1995 to 2005, he was Professor of Art History at the University of Tartu (as of 2006, Professor Emeritus of the University of Tartu; and from 2003 to 2006, the Pro-Rector of the University of Tartu.

5 Jaak Kangilaski, Kunstist, Eestist ja eesti kunstist.

6 E.g., Jaak Kangilaski, "Mõtteid välismaa uuemast kunstist”, Sirp ja Vasar, 5.02.1971; 12.02.1971; 19.02.1971; 26.02.1971. 
art. $^{7}$ However, this meant delving into an extremely interesting web of questions, in which post-modernist art theory influenced by the New Left movement, the political youth movements in the West, and a kind of involuntary situation existed in Estonian culture, where the aesthetic beliefs influenced by pre-war modernism supporting cultural distinctiveness, and the changes in Estonian youth culture at the turn of the decade etc., intertwined in a very complicated way.

Kangilaski was the first to draw attention to the conflict between the leftist attitude of Western art theory and the attitude focused on the preservation of the national culture in Estonian art. Estonian artists were very interested in radical Western art, in the experiments in form and material, but were not willing to accept the new art theory hidden behind this. The nature of the conflict was even more complicated because the possibility that the local dislocated Marxism could skilfully use new leftism to manipulate the youth culture still existed. "Luckily the ruling system was so stagnated and stupid that it did not know how to harness new leftism in its own interests," Kangilaski wrote years later. ${ }^{8}$ The separation of Western post-modernist art practices from the art theory supporting it, the emphasis on the split and, in a way, schizophrenic impact on Estonian art, or actually on its more radical wing, is still one of the most significant propositions in the research related to the art in the 1960s and 70s. Any writings related to this period that aspire to authenticity cannot ignore this approach.

Jaak Kangilaski had the opportunity to test his position in practice, by not only discussing them in Tartu's intellectual circles but also with young artists, mainly Andres Tolts and Ando Keskküla, with whom his friendship lasted for many years.

In the study of Estonia's Stalinist-era art, in both defining the problems and drawing the conclusions, Jaak Kangilaski is undoubted the greatest authority. It is difficult to contradict the periodization and its rationale presented in part 1, volume 6 of the History of Estonian Art. Art histories comprised of several volumes are usually summarising and relatively compact surveys, but since, in this case, it has been preceded

7 E.g., Jaak Kangilaski, “Lääne kunst 1970. aastatel”, Almanahh „Kunst“, nr.1/1981 (Tallinn: Kunst, 1981), 46 -52; Jaak Kangilaski, "Lääne kunst 1980. aastate alguses", Sirp ja Vasar, Nr. 5, 6, 7; Jaak Kangilaski, „Neoavangard või transavangard?", Almanahh „Kunst", nr.1/1986 (Tallinn: Kunst, 1986), 8-16.

8 Jaak Kangilaski, Kunstist; Eestist ja eesti kunstist, 16. 
by advising students preparing both bachelor's and post-graduate theses and by articles and discussions in the press ${ }^{9}$, we can be grateful that the most complicated period of our history to date has been explored so thoroughly, based not only on archival materials, but that a systematic approach including periodization has been developed.

Another important topic is the same periodization of the Soviet period of Estonian art accompanied by analyses of the changes. I am convinced that his article on the power-minded differences in, and also interweaving of, the discourses based on national-conservativism and the avant-garde is one of the most-quoted articles related to post-war Estonian art history. ${ }^{10}$ This is also a position that cannot be ignored when dealing with this period. Therefore, young researchers have moved forward by broadening the topic. ${ }^{11}$

The methodological framework established by Jaak Kangilaski has made the subsequent exploration of this topic easier. I believe that although discussions may develop in and around it and repositioning can occur, it is impossible to disregard Kangilaski's point of departure. His work with history, in the archives and writing articles, has not diminished Kangilaski's passionate interest in history as art theory and philosophy. His continual interest in theoretical approaches was also revealed in his articles. ${ }^{12}$ It is logical to expect more articles and books from the author of such significant surveys and textbooks of art history in our cultural space ${ }^{13}$ and one should not forget that part 2 of volume 6 of the History of Estonian Art is in the preparatory stage, and he will also be included as one of the authors.

Jaak Kangilaski has substantially guided the teaching of art history, starting in the 1970s as an associate professor and later as a full professor.

9 E.g, Jaak Kangilaski, "Okupeeritud Eesti kunstiajaloo periodiseerimine”, Ajalooline ajakiri 1/ 1999, 23-29; Jaak Kangilaski, "Tänud ja vastuväited Eda Sepale” (response to E. Sepp’s article "Okupeeritud Eesti kunstiajaloo periodiseerimise probleemid ja naiskunstnike osakaal: Valve Janov, Silvia Jõgever, Kaja Kärner”), Ariadne lõng, 1-2/ 2002, 212-214.

10 Jaak Kangilaski, "Paradigma muutus 1970.aasate Lääne kunstis ja selle kajastus eesti kunstielus", Jaak Kangilaksi, Kunstist, Eestist ja eesti kunstist, 220 - 227.

11 Tõnis Tatar, "Esteetiline autonoomia ja ideoloogiline opositsioon Eesti NSV-s, ehk kuidas avangard minetas poliitilise otstarbe", Kunst ja reaalpoliitika, Eesti Kunstimuuseumi Toimetised 3[8] 2013 (Tallinn: Eesti Kunstimuuseum, 2013), 251 - 267.

12 Jaak Kangilaski, "Lisandusi postkolonialismi diskussioonile", Kunstiteaduslikke Uurimusi, 1-2/ 2011, 7-25.

13 E.g, Jaak Kangilaski, Üldine kunstiajalugu (Tallinn: Kunst, 1997); Ants Juske, Jaak Kangilaski, Reet Varblane, 20.sajandi kunst (Tallinn: Kunst, 1994); Sirje Helme, Jaak Kangilaski, Lühike Eesti kunsti ajalugu (Tallinn: Kunst, 1999). 
At his initiative, the Institute of Art History was founded at the State Art Institute of the Estonian S.S.R. (ERKI) ${ }^{14}$ during his tenure as the rector, and thereafter, when the teaching of art history at the University of Tartu fell into a state of confusion, he provided his full support for the survival and sustainability of this subject, which was probably of marginal importance for the university. Jaak Kangilaski feels a fundamental responsibility for the study and teaching of art history.

I am not sure how much such an erudite professor has believed in the objectivity and fairness of historical writing when composing his texts. But I am sure that he has believed that it is necessary and possible to try and understand extremely complicated, intertwined processes, which our life on this planet seems to be based on. Both his articles and lectures recommend this mindset to all thinking people.

Sirje Helme: Jaak Kangilaski - Scholar and Teacher

Keywords: Jaak Kangilaski, Art Historian, Post-War Estonian Art, Professor of Art History

CV:

Sirje Helme (PHD) is Director-General of the Art Museum of Estonia. Her main research field is post-war art (modernism and avant-garde) in Estonia and East-Central Europe. Lecturer at the University of Tartu and the Estonian Academy of Arts, professor at the University of Tartu from 2012 to 2013.

Articles have been published in several international journals; the author of A Concise History of Estonian Art, 1999 (co-author Prof. Jaak Kangilaski, translated into Finnish in 2001); Popkunst Forever. Estonian Pop Art at the Turn of the 1960s and 1970s, 2010; co-author of History of Estonian Art 1940-1990, volume 6, 2013; organizer of many conferences and seminars; editor of collections of critical essays (Nosy Nineties.

14 From 1989 to 1995, the Tallinn University of Art; since 1996 until the present the Estonian Academy of Arts. 
Problems, Themes and Meanings in Estonian Art on 1990s, 2001; Lost Eighties. Problems, Themes and Meanings in Estonian Art on 1980s, 2010); and the Proceedings of the Art Museum of Estonia ("Different Modernisms, Different Avant-Gardes. Problems in Central and Eastern European Art after World War II", 2009; "Art and Political Reality", 2013). 
